\title{
Agglutinated Foraminifera from the Northern Tarcău Nappe (Eastern Carpathians, Romania)
}

\author{
Raluca BINDIU* \& Sorin FILIPESCU \\ Department of Geology, “Babeş-Bolyai” University, Kogălniceanu 1, 400084 Cluj-Napoca, Romania
}

Received August 2011; accepted October 2011

Available online 31 October 2011

DOI: $10.5038 / 1937-8602.56 .2 .4$

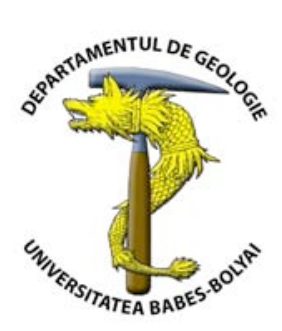

\begin{abstract}
The Tarcău Nappe is the most important unit of the Carpathian flysch due to its size, stratigraphic and tectonic complexity. Our purpose was to identify the major types of foraminifera assemblages in relation to the paleoenvironmental settings and their biostratigraphic potential. The identified assemblages are characteristic to the Cretaceous and Paleogene, consisting mostly of benthic agglutinated and, in lower proportions, benthic calcareous and planktonic species. Local abundances of Glomospira allowed the correlation of the examined strata to the early Eocene "Glomospira event" described from the Carpathians in Poland, Morocco, and Labrador. Rzehakina fissistomata (Grzybowski) identified at Palma makes possible the correlation of these deposits to the Paleocene Rzehakina fissistomata Zone. Paleoenvironmental conditions (depth, amount of oxygen, nutrients) could be inferred based on specific assemblages and compared to the already described types of facies from the Carpathians.
\end{abstract}

Key words: Paleogene, foraminifera, morphogroups, paleoenvironments, Glomospira event.

\section{INTRODUCTION}

Agglutinated foraminifera have been used for biostratigraphic and paleoecologic purposes since the end of the 19th century for the deep-sea turbiditic sequences of the Alpine - Carpathian region. They represent the most widely distributed and most abundant micropaleontological component of the flysch deposits (Morgiel and Olszewska, 1981). For this reason, we concentrated on the potential value of this group of microfossils for biostratigraphy and paleoenvironmental reconstructions.

The Tarcău Nappe is the median unit of the "external flysch" (Moldavides), extending from Suceava Valley (north) to Dâmbovița (south) (Mutihac and Ionesi 1974; Săndulescu, 1984). The characteristic formations and the nappe-style tectonic configuration are the result of the regional tectonics and associated depositional processes produced between the Cretaceous to Pliocene (Mutihac and Ionesi, 1974).

In the Carpathians, the foraminifera from the equivalent formations have been thoroughly studied since the work of Grzybowski $(1894,1896,1898,1901)$ to the more recent contributions (Bak et al., 1997; Bąk, 2004; Bąk, 2007; Bubík, 1995; Kender et al., 2005; Olszewska, 1997; Oszczypko et al., 2005; Szydło, 2011; Waśkowska, 2011). In Romania, the micropaleontological assemblages from the "external flysch" were studied by Tocorjescu $(1954,1960)$ focused on the Cretaceous and the Cretaceous/Eocene boundary, Ionesi (1974) on the Paleocene and Neagu et al. (1992) on the biostratigraphy of the early Albian to the early Paleocene agglutinated foraminifera. The stratigraphy and micropalentology of the Turonian to Paleocene flysch of the Tarcău Unit were discussed by Săndulescu (1973), who mentioned 60 agglutinated taxa. The same author published in 1975 a summary of the Late Cretaceous to Paleocene foraminiferal assemblages from the Tarcău Unit.

The present study has been focused on identifying the main types of foraminifera assemblages in the northern part of the Tarcău Nappe, between Suceava and Bistrița valleys as a preliminary step for the biostratigraphic zonation and for paleoenvironmental reconstructions in the turbiditic systems.

\section{MATERIAL AND METHODS}

Samples were collected from several representative finegrained siliciclastic turbidites outcropping of the Northern Tarcău Nappe at Săcrieş (N 47.75061; E 25.62286), Suceava (N 47.87150; E 25.39642), Palma (N 47.75005; E 25.63921), Straja (N 47.91389; E 25.49552), Rusca (N 47.76001; E 25.65243), Putna (N 47.86326; E 25.59334), Grozăvesti (N 47.05128; E 26.03993), Buhalnița (N 47.00969; E 26.08761) and Potoci (N 46.98584; E 26.10657) (Fig. 1). $250 \mathrm{~g}$ of sediment were processed for each sample by standard micropaleontological methods and then washed over a $63 \mu \mathrm{m}$ sieve; 300 individuals were picked from each sample. The morphogroups were separated based on the classification of Kaminski and Gradstein (2005). Individual specimens were photographed using the scanning electron microscope at the Center of Electron Microscopy of the "Babeş-Bolyai" University.

\section{RESULTS}

Johnes and Charnock (1985) proposed the deep-water agglutinated foraminifera (DWAF) morphogroups, defined 
by test shape and chamber arrangement. Morphogroup analysis is based on the assumption that the morphology of the foraminiferal test is connected to the feeding strategy of benthic taxa, and therefore with their microhabitat preferences. Other authors like Nagy (1992), Nagy et al.,
(1995), Bąk et al., (1997), Van der Akker et al., (2000), Kaminski and Gradstein (2005), Cetean et al., (2011), further refined and enhanced the morphogroup analyses based on agglutinated foraminifera for palaecological interpretation.

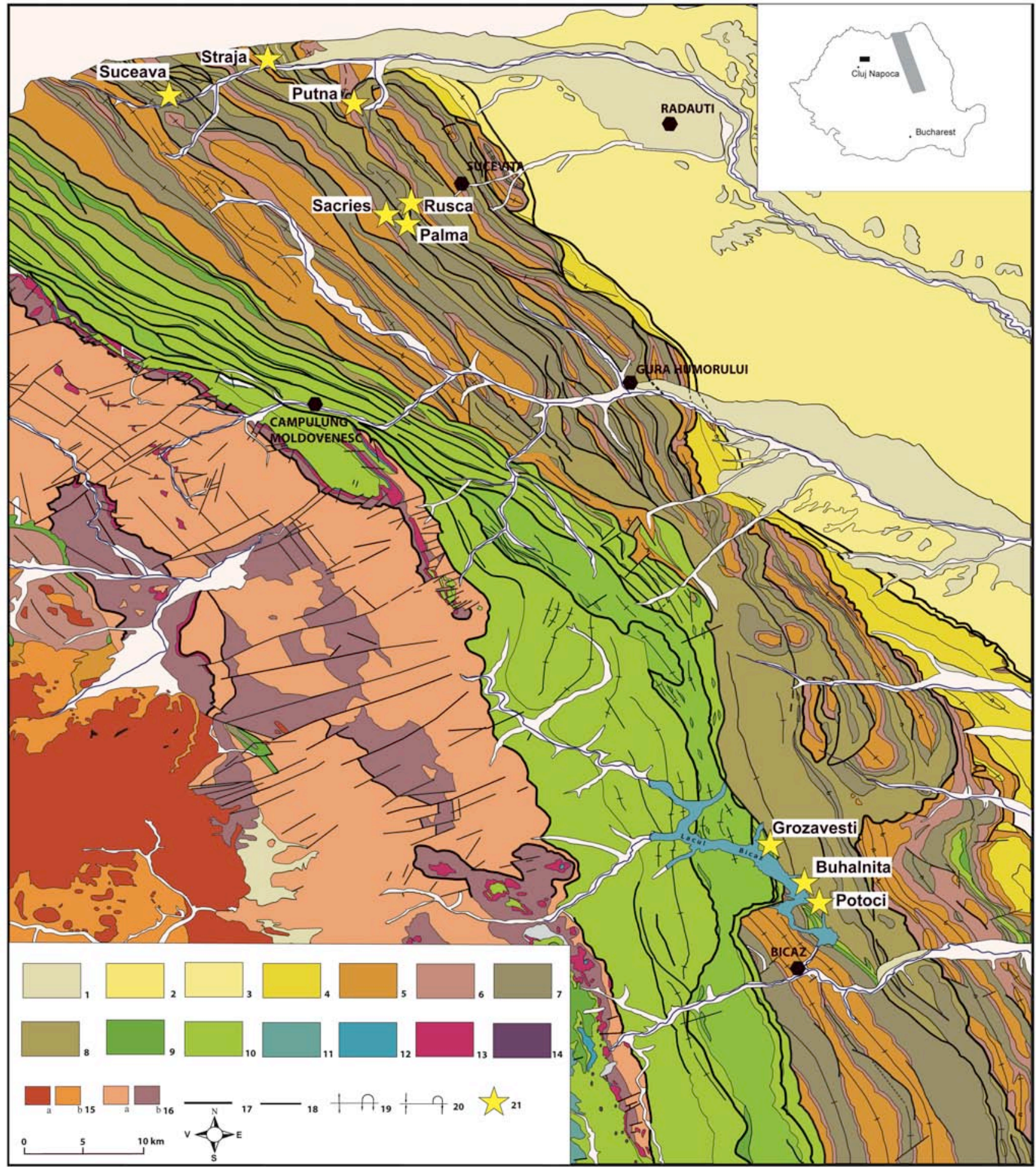

Fig. 1. Location of the investigated sections. 1 - Quaternary, 2 - Badenian, 3 - Sarmatian, 4 - Burdigalian, 5 - Oligocene, 6 - Eocene,

7 - Paleocene - Eocene, 8 - Late Cretaceous - Paleocene, 9 - Late Cretaceous, 10 - Early Cretaceous, 11 - Late Jurassic - Early Cretaceous, 12 - Middle Jurassic - Late Jurassic, 13-Triassic, 14 - Mesozoic magmatites, 15 - Neogene magmatites (a - magmatic rocks, $b$-volcano-sedimentary formation), 16 - Metamorphic rocks ( $a$ - epimetamorphites, $b$ - mesometamorphites), 17 - faults, 18 - digitations, 19 - anticline (symmetrical, overturned), 20 - syncline (symmetrical, overturned), 21 - location of the investigated sections. (modified after the Geological Map of Romania, 1:200.000, Rădăuţi, Suceava, Piatra Neamţ, and Topliţa sheets).

Characteristic features of the benthic agglutinated assemblages in the investigated area include: a) occurrence in the fine grained interval of the turbidite sequences; b) agglutinated taxa are dominant, with or without minor amounts of calcareous benthic forms; d) cosmopolitan distribution; e) coarse grained and medium sized tests are dominant. Three types of agglutinated foraminiferal assemblages were recognized: 


\section{Assemblages with tubular agglutinated foraminifera}

The assemblages dominated by tubular forms were identified in the Upper Cretaceous to Eocene mid to distal fan turbidites from the Suceava Valley, and around Putna, Buhalniţa and Potoci localities. The assemblage is characterized by opportunistic forms, as: Bathysiphon sp., Nothia excelsa (Grzybowski), Rhabdamina sp. and lower proportions of Amolagena clavata (Jones and Parker), Glomospira charoides (Jones and Parker), Caudammina ovula (Grzybowski), Psammosphaera irregularis (Grzybowski) (Plate I).

The dominant forms belong to morphogroup M1 in the classification of Kaminski and Gradstein (2005); it includes epifaunal tubular taxa with a suspension feeding strategy. Their erect life position was adapted to environments with a low organic influx. By analizing the distribution of the morphogroups (Fig. 2), it can be observed that the tubular forms are present in proportions higher than $50 \%$ compared to the other morphogroups. According to Jones and Charnock (1985), the significant presence of this morphogroup suggests lower bathyal to abyssal deep-water settings with low, but constant organic flux brought in by the deep-water currents. It's worth mentioning that in all investigated areas ichnofossils are present, indicating high oxygen levels on the substrate.

As shown by the position of the examined sections (Fig. 1), the tubular agglutinated assemblages are located all along the Tarcău Nappe. This suggests that similar environment conditions existed along large areas of the basin at the time of deposition.
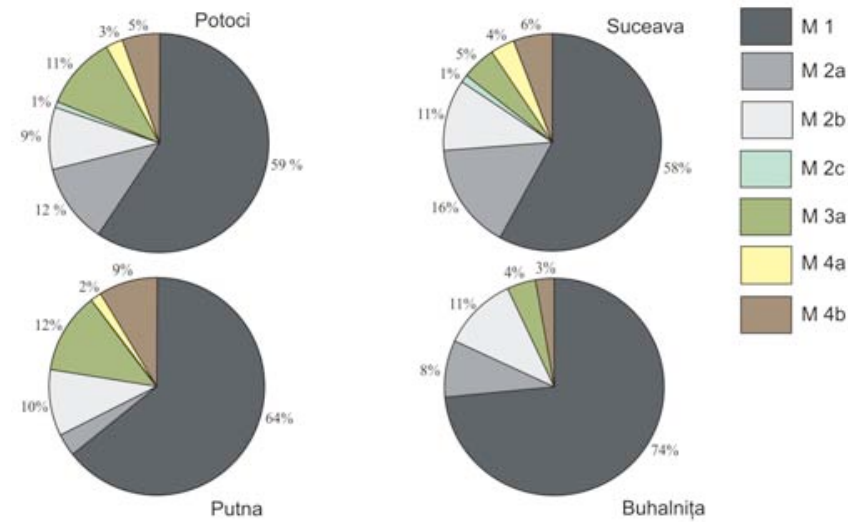

Fig. 2. Proportion of agglutinated morphogroups at Putna, Suceava, Buhalnița, Potoci (high ratio of M1).

Morphogroups: M1 - tubular; M2a - globular; M2b - rounded trochospiral and streptospiral; M2c - elongate keeled; M3a-flattened planispiral and streptospiral;

M4a -rounded planispiral; M4b - elongate subcylindrical.

\section{Assemblage with Glomospira spp.}

This type of assemblage was identified in the Straja area (Fig. 1) and was separated based on the higher presence of Glomospira charoides (Jones and Parker) and Glomospira gordialis (Jones and Parker) (Fig. 3 and Plate II) mainly in variegated shales (red, green and subordinate grey shales alternating with decimetric sandstones). These species belong to the M3a morphogroup of Kaminski and Gradstein (2005). Recent similar assemblages have been reported from marginal marine environments (marshes and lagoons) (Nagy et al., 1995). The numerous specimens of Glomospira make possible the correlation with similar Eocene (Ypresian/
Lutetian) deposits from the Polish Carpathians, Morocco and Labrador (Morgiel and Olszewska, 1981; Morgiel and Olszewska, 1982; Kaminski et al., 1989; Kaminski et al., 1996). The identified small sized specimens are similar to the ones described from the Polish Carpathians (Bak, 2004). Such small sizes might have been caused by sudden food pulses leading to rapid growth and reproduction cycles (Gooday, 1993), high water temperature causing increased metabolic food requirements (Boersma et al., 1998), or oxygen deficiency in warm bottom waters (Thompson et al., 1985).

Kaminski et al. (1989) considered that the Glomospira abundance event was produced by a rise in the CCD in bathyal to abyssal paleodepths; it represented an interval of lower sedimentation rate and high surface productivity that caused low oxygen levels at the seafloor. However, this assemblage also occurs in well-oxygenated environments and therefore it may be opportunistic re-colonizer rather than a reliable indicator for high productivity (Kaminski et al., 1996).

Based on the presence of this assemblage in variegated shales and according to the work of Kender et al., (2005), we believe that the paleoenvironmental conditions presented by Kaminski et al. (1989) best fit for the deposits at Straja.

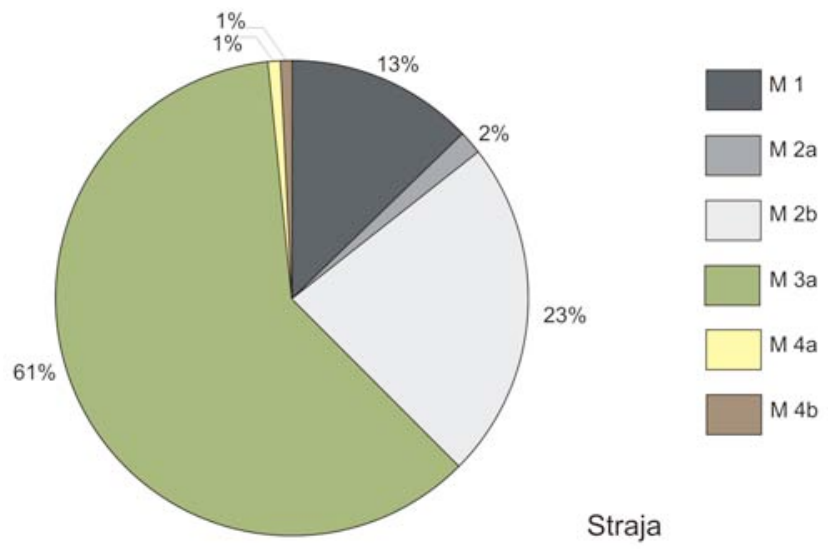

Fig. 3. Distribution of agglutinated morphogroups at Straja, showing a high ratio of M3a. Morphogroups: M1 - tubular; M2a - globular; M2b - rounded trochospiral and streptospiral; M2c - elongate keeled; M3a-flattened planispiral and streptospiral; $M 4 a$ - rounded planispiral; M4b-elongate subcylindrical.

\section{Assemblages with Karrerulina spp.}

Statistic analysis of the morphogroups from the sites near the Rusca valley and Grozăveşti village shows high proportions of seriate foraminifera (Fig. 4). These were included in the M4b morphogroup of Kaminski and Gradstein (2005) and are represented by Karrerulina conversa (Grzybowski), Karrerulina horida (Mjatliuk), Karrerulina apicularis (Cushman) and Karrerulina coniformis (Grzybowski). In lower proportions occur species belonging to other morphogroups: Rhabdammina linearis Brady, Saccammina placenta (Grzybowski), Caudammina ovula (Grzybowski), Glomospira irregularis (Grzybowski), Ammodiscus latus Grzybowski, Rzehakina fissistomata (Grzybowski) (Plate III).

Similar assemblages were identified in the Polish Carpathians by Bak (2004), considered as early Eocene in age (above the Glomospira acme). Due to the reduced dimensions of the species, they were associated to rapidly 
disturbed or varying environments indicating increased circulation of the bottom waters, a low sedimentation rate, oxygenated waters and oligotrophic conditions at the sea floor (Bąk, 2004).
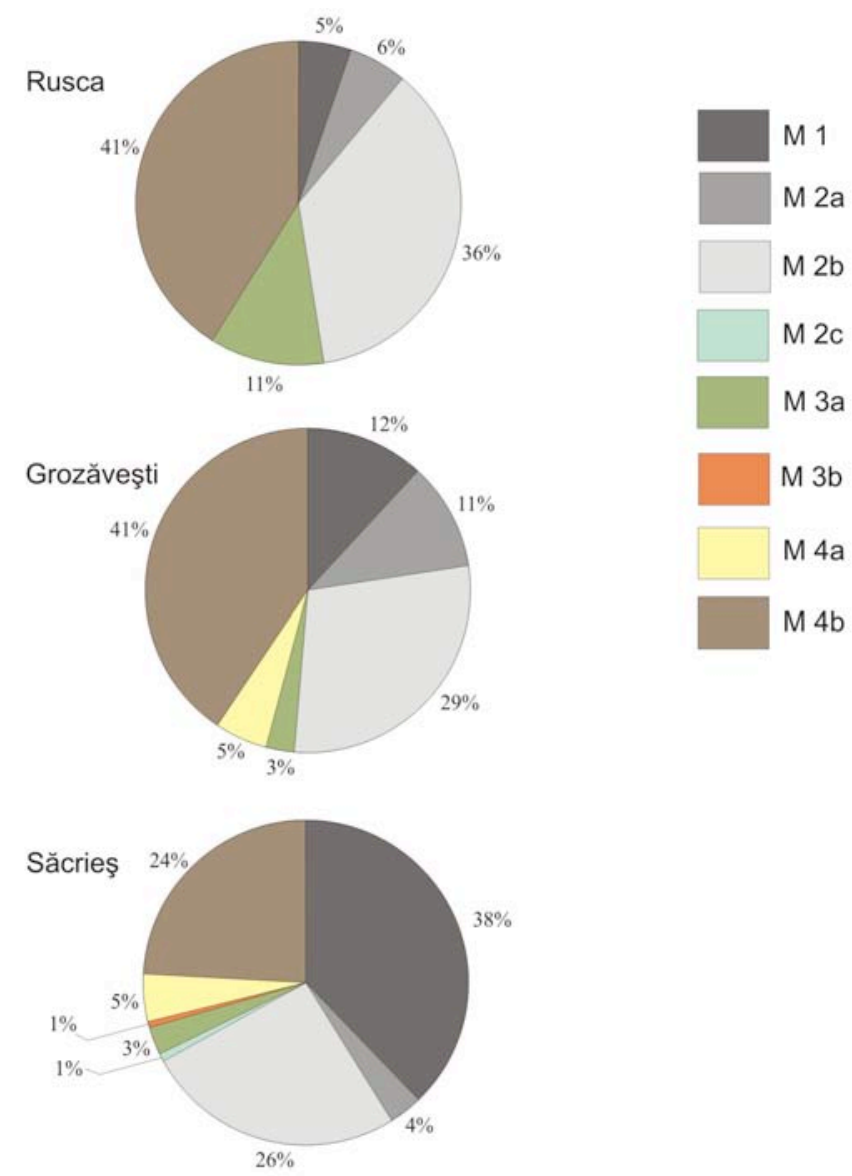

Fig. 4. Morphogroups from Rusca, Grozăveşti (high ratio of M4b) and Săcrieş (transitional assemblage). Morphogroups:

M1- tubular; M2a-globular; M2b - rounded trochospiral and streptospiral; M2c - elongate keeled; M3a-flattened planispiral and streptospiral; $M 3 b$-flattened irregular; $M 4 a$-rounded planispiral; M4b - elongate subcylindrical.

The regular sized specimens in our samples match the hypothesis of Nagy et al. (1997) who state that the elongate subcylindrical forms live in a deep infaunal habitat with increased organic flux and higher nutrient supply; they scavenge the sediment for bacteria and detritus (Nagy, 1992; Nagy et al., 1995). They are most common in inner shelf to upper bathyal environments with moderate contributions in lagoonal and marsh environments (Nagy et al., 1995).

Following the analysis of the morphogroups ratio, we consider the association from the Săcrieş to be transitional (Fig. 4). Tubular forms, accounting for $38 \%$ of the identified individuals, are represented by forms as Bathysiphon sp., Nothia excelsa (Grzybowski), Rhabdamina sp, Rhizammina sp.; the rounded trochospiral and streptospiral forms account for $26 \%$, while the elongate subcylindrical forms are exclusively represented by Karrerulina conversa and, Karrerulina coniformis.

From a paleoecological point of view, the significant presence of the three morphogroups suggests fluctuations in the amount of organic matter and oxygen levels, and distal shelf to bathyal environments.

A specific assemblage with Rzehakina fissistomata (Grzybowski) has been identified at Palma (Fig. 1; Plate I,
17). This was considered as an index species in Poland Carpathians for the Paleocene (Rzehakina fissistomata Zone - Geroch and Novak, 1984; Gryzbowski, 1901; Olszewska, 1997) and indicates bathyal environments. Data on the presence of Rzehakina fissistomata in the Romanian Eastern Carpathians, were given by Săndulescu (1973, 1975), Ionesi (1974) and Neagu et al. (1992).

\section{CONCLUSIONS}

Deep-sea benthic foraminifera assemblages in the northern Tarcău Nappe are dominated by the agglutinated taxa. The agglutinated assemblages were included in three morphogroups according to test shape, life habitat and feedig strategy.

These assemblages fit very well into the "flysch-type" agglutinated foraminiferal biofacies characteristic for the middle-lower bathyal settings (Kaminski and Gradstein, 2005). "Flysch type" assemblages are well represented in high latitudes and in areas where the rapid deposition of clastic sediments creates a benthic environment unfavorable for the preservation of carbonate test.

Based on the high proportions of tubular foraminifera, the deposits from Suceava, Putna, Buhalniţa and Potoci can be characterized by marine lower bathyal to abyssal deep water environments, with low but constant organic flux.

The numerous specimens of Glomospira identified in the variegated shales from Straja indicate a lower sedimentation rate, high surface productivity and low oxygenation.

The abundance of Karrerulina spp. at Rusca, Grozăveşti and Săcrieş suggests inner shelf to upper bathyal environments with a low sedimentation rate, increased circulation of the bottom waters, increased organic flux and higher nutrient supply.

The majority of the recorded agglutinated species is long-ranging and cannot give a good biostratigraphic resolution. Rzehakina fissistomata from Palma has been considered as indicator for the Danian, abundant Glomospira suggests early Eocene age for the Straja deposits, while high numbers of Karrerulina have been treated as indicators for the early Eocene (above the Glomospira acme). These assemblages can be well correlated to the Paleocene-Eocene assemblages of the Polish Carpathians.

Acknowledgments. This work was supported by the Sectoral Operational Programme for Human Resources Development 2007-2013, co-financed by the European Social Fund, under the project No. POSDRU/107/1.5/S/76841 entitled "Modern Doctoral Studies: Internationalization and Interdisciplinarity". The fieldwork was supported by S.N.G.N. Romgaz S.A., project No. 90/2009.

\section{R E F E R E N C E S}

Bąk, K. 2004, Deep-water agglutinated foraminiferal changes across the Cretaceous/Tertiary and Paleocene/Eocene transitions in the deep flysch environment; eastern Outer Carpathians, (Bieszczady Mts., Poland). In Proceedings of the Sixth International Workshop on Agglutinated Foraminifera (Bubík, M. \& Kaminski, M.A., Eds.). Grzybowski Foundation Special Publication, 8: 1-56. 
Bąk, K. 2007, Environmental changes around the Cenomanian - Turonian boundary in a marginal part pf the outer Carpathian basin expressed by microfacies, microfossils and chemical records in the Skole Nappe (Poland). Annales Societatis Geologorum Poloniae, 77: 39-67.

Bąk, K., Bąk, M., Geroch, S. \& Manecki, M. 1997 , Biostratigraphy and paleoenvironmental analysis of benthic foraminifera and radiolarians in Paleogene variegate shales in the Skole Unit, Flysch Carpathians. Annales Societatis Geologorum Poloniae, 67: 135-154.

Boersma, A., Premoli Silva, I. \& Hallock, P. 1998, Trophic models for the well-mixed and poorly mixed warm oceans across the Paleocene/Eocene epoch boundary. In Late Paleocene-early Eocene climatic and biotic events in the marine and terrestrial records (Aubry, M.P., Lucas, S.G. \& Berggren, W.A., Eds.). Columbia University Press, New York, 204-213.

Bubík, M. 1995, Cretaceous to Paleogene agglutinated foraminifera of the Bile Karpaty Unit (West Carpathians, Czech Republic). In Proceedings of the Fourth International Workshop on Agglutinated Foraminifera (Kaminski, M.A., Geroch, S. \& Gasiñski, M.A., Eds.). Grzybowski Foundation Special Publication, 3: 71-116.

Cetean, C.G., Bălc, R., Kaminski, M.A. \& Filipescu, S. 2011, Integrated biostratigraphy and palaeoenvironments of an upper Santonian - upper Campanian succession from the southern part of the Eastern Carpathians, Romania. Cretaceous Research, 32: 575-590.

Geroch, S., Nowak, W. 1984, Proposal of zonation for the late Tithonian - late Eocene, based upon arenaceous foraminifera from the outer Carpathians, Poland. In Benthos '83: $2^{\text {nd }}$ International Symposium on Benthic Foraminifera (Pau 1983) (Oertli, H.J., Ed.) Elf Aquitaine, Esso REP and Total CFP, Pau and Bordeaux, 6: 225-239.

Gooday, A.J. 1993, Deep-sea benthic foraminiferal species which exploit phytodetritus: characteristic features and controls on distribution. Marine Micropaleontology, 22: 187-205.

Grzybowski, J. 1894, The microfauna of the Carpathian Sandstones from the environs of Dukla. Rozprawy Akademii Umiejętności $w$ Krakowie, Wydziat Matematyczno-Przyrodniczy, Kraków, ser. 2, 29: 181214 (In Polish).

Grzybowski, J. 1896, The foraminifera of the Red Clays from Wadowice. Rozprawy Akademii Umiejętności $w$ Krakowie, Wydziat Matematyczno-Przyrodniczy, Kraków, ser. 2, 30: 261-308 (In Polish).

Grzybowski, J. 1898, The foraminifera of oil - bearing beds in the vicinity of Krosno. Rozprawy Akademii Umiejętności w Krakowie, Wydziat MatematycznoPrzyrodniczy, Kraków, ser. 2, 33: 257-305 (In Polish).

Grzybowski, J. 1901, The foraminifera of the Inoceramus beds in the vicinity of Gorlice. Rozprawy Akademii Umiejętności w Krakowie, Wydziat MatematycznoPrzyrodniczy, Kraków, ser. 2, 41: 219-286 (In Polish).

Ionesi, L. 1974, The Paleocene from the External Carpathian Flysch. Analele Ştiinţifice ale Universităţii "Al. I. Cuza” Iaşi, XX: 93-100 (In Romanian).

Jones, R.W, Charnock, M.A. 1985, "Morphogroups" of agglutinating foraminifera. Their life position, feeding habitats and potential applicability in (paleo)ecological studies. Revue Paleobiology, 4: 311-320.
Kaminski, M.A., Gradstein, F.M. \& Berggren, W.A. 1989, Paleogene benthic foraminiferal stratigraphy and paleoecology at Site 647, southern Labrador Sea. In Proc. ODP, Sci. Results, 105 (Srivastava, S.P, Arthur, M.A, Clement, B., et al., Eds.), College Station, TX (Ocean Drilling Program), 705-730.

Kaminski, M.A., Kuhnt, W. \& Radley, J. 1996, PaleoceneEocene deep water agglutinated foraminifera from the Numidian Flysch (Rif, Northern Morocco): their significance for the Paleoceanography of the Gibraltar Seaway. Journal of Micropalaeontology, 15: 1-19.

Kaminski, M.A., Gradstein, F.M. 2005, Atlas of Paleogene cosmopolitan deep-water agglutinated foraminifera. Grzybowski Foundation, 547 p.

Kender, S., Kaminski, M.A. \& Cieszkowski, M. 2005, Foraminifera from the Eocene Variegated Shales near Barwinek (Magura Unit, Outer Carpathians), the type locality of Noth (1912) revisited. Annales Societatis Geologorum Poloniae, 75: 249-271.

Morgiel, J., Olszewska, B. 1981, Biostratigraphy of the Polish external Carpathians based on agglutinated foraminifera. Micropaleontology, 27 (1): 1-24.

Morgiel, J., Olszewska, B. 1982, Uniformity of the Tethyan faunas from Cretaceous and Paleogene as shown by foraminifera from Morocco and Polish Flysch Carpathians. Cahiers de Micropaleontologie, 3: 45-53.

Mutihac, V., Ionesi, L. 1974, The geology of Romania. Editura Tehnică, Bucureşti, 646 p. (In Romanian).

Neagu, T.H., Platon, E., Dumitrescu, G. \& Selea, L. 1992, The biostratigraphical significance of agglutinated foraminifera in the Eastern Carpathians (Upper Cretaceous). Analele Universităţii Bucureşti, 15-16: 45-49.

Nagy, J. 1992, Environmental significance of foraminiferal morphogroups in Jurassic North Seadeltas. Palaeogeography, Palaeoclimatology, Palaeoecology, 95: 111134.

Nagy, J., Gradstein, F.M., Kaminski, M.A. \& Holbourn, A.E. 1995, Foraminiferal morphogroups, paleoenvironments and new taxa from Jurassic to Cretaceous strata of 41Thakkhola, Nepal. In Proceedings of the Fourth International Workshop on Agglutinated Foraminifera (Kaminski, M.A., Geroch, S. \& Gasinski, M.A., Eds.). Grzybowski Foundation Special Publication, 3: 181-209.

Nagy, J., Kaminski, M.A., Johnsen, K. \& Mitlehner, A.G. 1997, Foraminiferal, palynomorph, and diatom biostratigraphy and paleoenvironments of the Torsk Formation: A reference section for the Paleocene-Eocene transition in the western Barents Sea. In Contributions to the Micropaleontology and Paleoceanography of the Northern North Atlantic (Hass, H.C., Kaminski, M.A., Eds.). Grzybowski Foundation Special Publication, 5: 15-38.

Olszewska, B. 1997, Foraminiferal biostratigraphy of the Polish Outer Carpathians: a record of basin geohistory. Annales Societatis Geologorum Poloniae, Krakow, 67 (2-3): 325-337.

Oszczypko, N., Malata, E., Bąk, K., Kêdzierski, M. and Oszczypko-Clowes, M. 2005, Lithostratigraphy and Biostratigraphy of the Upper Albian-Lower / Middle Eocene flysch deposits in the Bystrica and Raèa subunit softhe Magura Nappe (Beskid Wyspowyand Gorce Ranges; Poland). Annales Societatis Geologorum Poloniae, 75: 27-69. 
Săndulescu, J. 1973, Étude micropaléontologique et stratigraphique du flisch du Crétacé supérieur Paléocéne de la region de Brețcu - Comandău (Secteur intern meridional de la Nappe de Tarcău - Carpates Orientales). Memoriile Institutului Geologic, XVII: 1-52.

Săndulescu, J. 1975, Microbiostratigraphie, associations et zones a foraminifers du Cretace du Flisch Externe des Carpates Orientales (Roumanie). Revista Espagnola de Micropaleontologia, VII (1): 99-111.

Săndulescu, M. 1984, Geotectonics of Romania. Ed. Tehnică, Bucureşti, 334 p. (In Romanian).

Szydło, A. 2011, Agglutinated foraminifers from event deposits - an example from the Northern Outer Carpathians. In Proceedings of the Eighth International Workshop on Agglutinated Foraminifera (Kaminski, M.A., Filipescu, S., Eds.). Grzybowski Foundation Special Publication, 16: 317-330.

Thompson, J.B., Mullins, H.T., Newton, C.R. \& Vercoutere, T.L. 1985, Alternative biofacies model for dysaerobic communities. Lethaia, 18: 167-179.

Tocorjescu, M. 1954, Study of Late Cretaceous Globotruncana from the Flysch zone. Dări de Seamă ale Comitetului Geologic Bucureşti, XXXVIII: 215-228 (In Romanian).
Tocorjescu, M. 1960, Micropalaentological considerations on the Cretaceous - Eocene boundary. Studii şi Cercetări Geologice. Academia R. P. R., Bucureşti, V: 277-297 (In Romanian).

Van Der Akker, T., Kaminski, M.A. \& Gradstein, F.M., Wood, J. 2000, Campanian to Palaeocene biostratigraphy and palaeoenvironments in the Foula Basin, west of Shetland Islands. Journal of Micropalaeontology, 19: 23-43.

Waskowśka, A., 2011, The Early Eocene Saccamminoides carpathicus Assemblage in the Outer Flysch Carpathians. In Proceedings of the Eighth International Workshop on Agglutinated Foraminifera (Kaminski, M.A., Filipescu, S., Eds.). Grzybowski Foundation Special Publication, 16: 331-341.

***1968, Geological Map of Romania, 1:200.000, Rădăuți Sheet, Geological Institute, Bucharest.

***1966, Geological Map of Romania, 1:200.000, Suceava Sheet, Geological Institute, Bucharest.

***1968, Geological Map of Romania, 1:200.000, Piatra Neamț Sheet, Geological Institute, Bucharest.

***1968, Geological Map of Romania, 1:200.000, Toplița Sheet, Geological Institute, Bucharest.

Plate I. Assemblage with dominant tubular agglutinated foraminifera.

1. Bathysiphon sp. 1.

2. Bathysiphon sp. 2.

3. Nothia sp. 1.

4. Nothia latissima (Grzybowski).

5. Nothia sp. 2.

6, 7. Nothia excelsa (Grzybowski).

8, 9. Hyperammina rugosa Verdenius and Van Hinte.

10. Hyperammina elongata Brady.

11. Rhabdammina ex. gr. discreta Brady.

12. Rhizammina algaeformis Brady.

13. Rhizammina indivisa Brady.

14. Psammosphaera irregularis (Gryzbowski) emend. Liszka \& Liszkowa.

15. Lituotuba lituiformis (Brady).

16. Caudammina ovula (Grzybowski).

17. Rzehakina fissistomata (Grzybowski). 

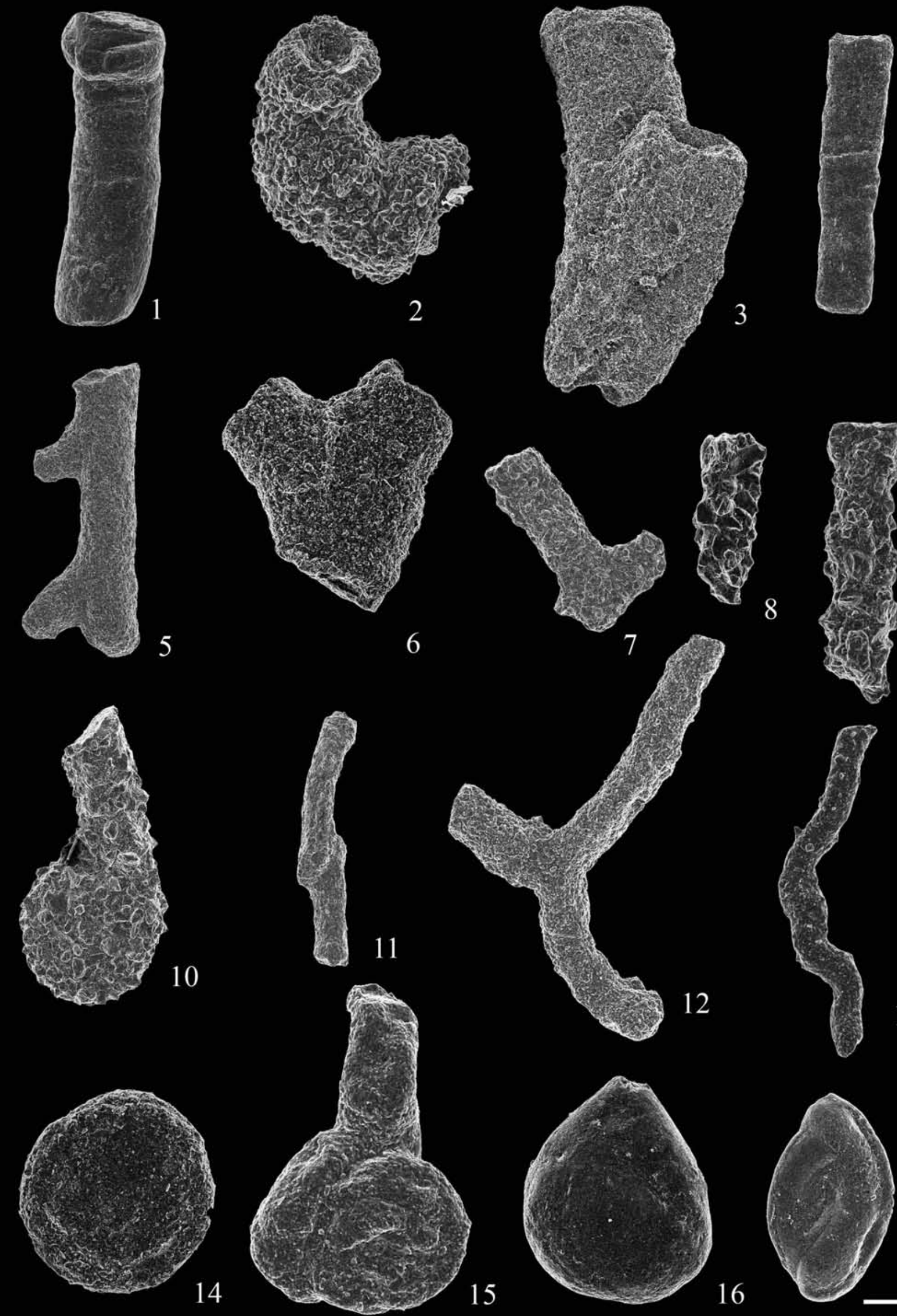

15
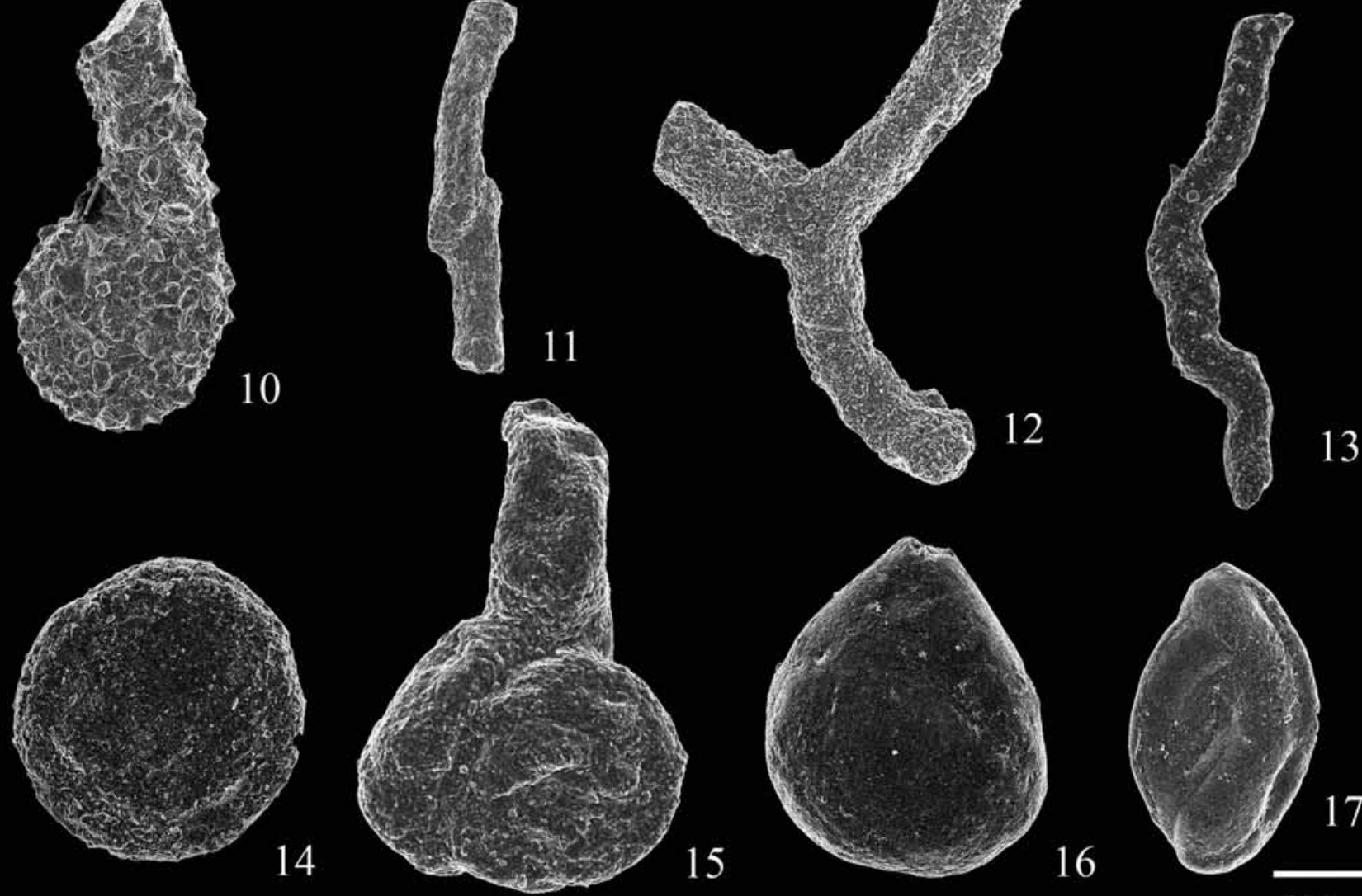
Plate II. Assemblage with Glomospira.

1, 2, 4. Glomospira gordialis (Johnes \& Parker).

3. Glomospira serpens (Grzybowski).

5. Glomospira charoides (Johnes \& Parker).

6. Glomospira diffundens (Cushman \& Renz).

7. Nothia latissima (Grzybowski).

8. Psammosphaera irregularis Grzybowski.

9. Psammosphaera fusca Schultze emend., Heron-Allen \& Earland.

10. Saccammina grzybowski (Schubert).

11. Trochamminoides subcoronatus (Grzybowski). 


\section{PLATE II}
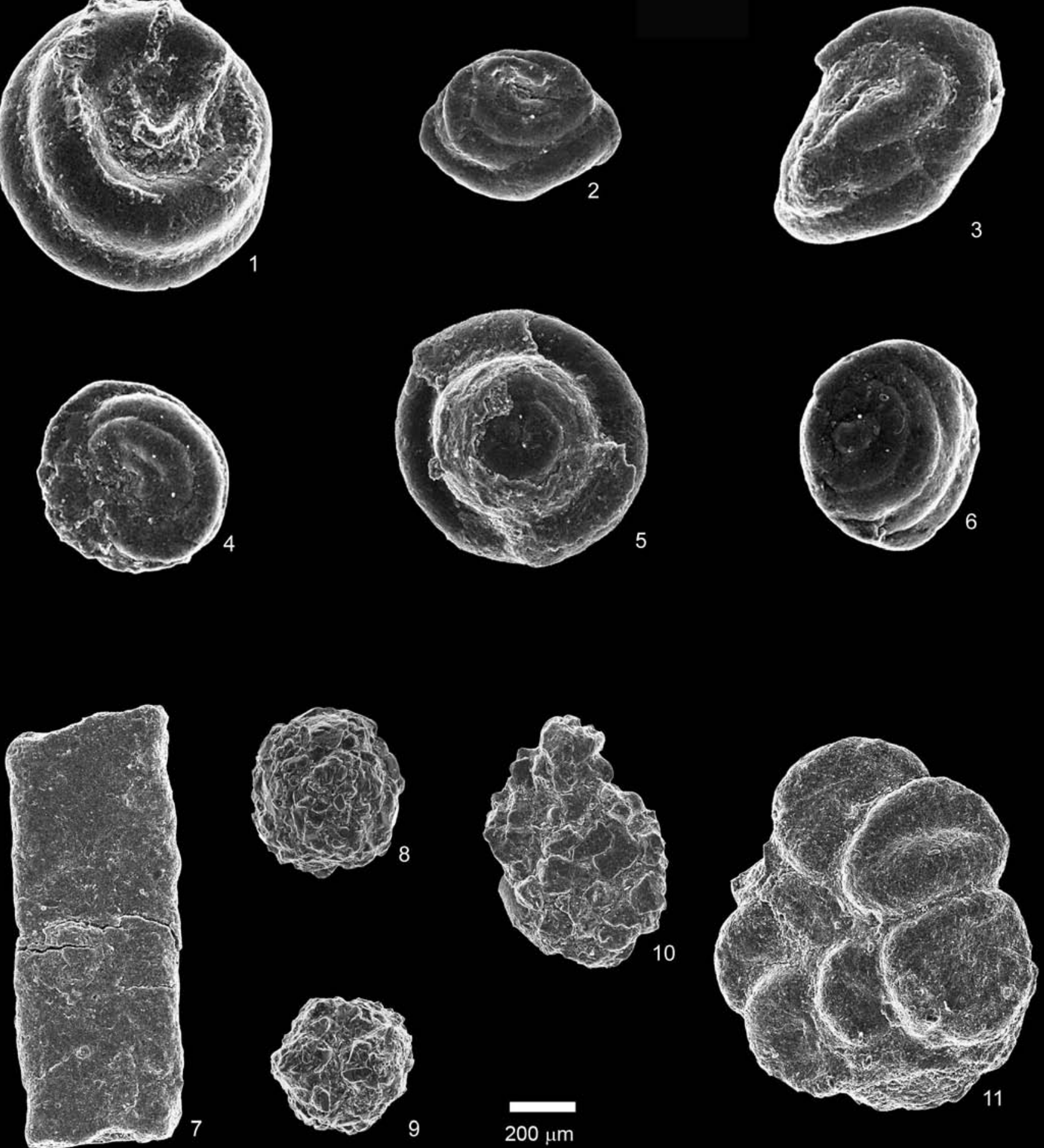

Studia UBB Geologia, 2011, 56 (2), 31 - 41 
Plate III. Assemblage with Karrerulina.

1, 2, 3, 5, 6, 7. Karrerulina conversa (Grzybowski).

4, 8, 10. Karrerulina horrida (Mjatliuk).

9. Clavulinoides $\mathrm{sp}$.

11. Haplophragmoides sp.

12. Haplophragmoides kirki Wickenden.

13. Haplophragmoides walteri (Grzybowski).

14. Trochamminoides sp.

15. Trochamminoides subcoronatus (Grzybowski).

Studia UBB Geologia, 2011, 56 (2), 31 - 41 


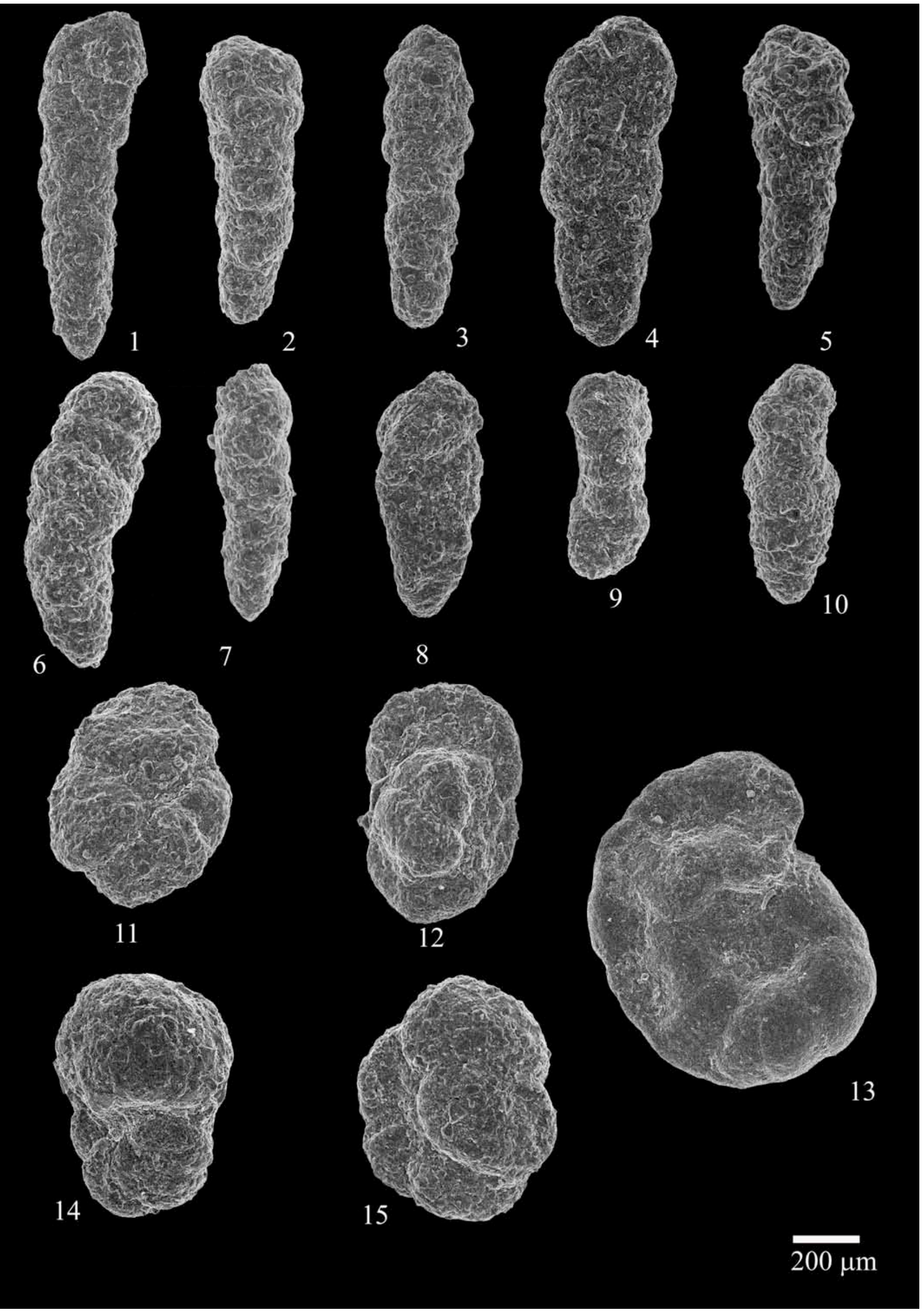

